\title{
The Relationship between Working Capital Management and Profitability: Evidence from Pakistan
}

\author{
Nadeem Iqbal ${ }^{1, \star}$, Naveed Ahmad ${ }^{2}$, Zeeshan Riaz ${ }^{3}$ \\ ${ }^{1}$ Faculty of Management Sciences, Baha Uddin Zakariya University, Multan 6000, Punjab, Pakistan \\ ${ }^{2}$ Faculty of Management Sciences, Indus International Institute, D. G. Khan, Punjab, Pakistan \\ ${ }^{3}$ Baha Uddin Zakariya University, Multan 6000, Punjab, Pakistan \\ ${ }^{\star}$ E-mail address: drnadeemiqbal1@gmail.com
}

\begin{abstract}
In this paper secondary data is used for analysis of working capital on profitability. In this research paper we take working capital as independent variable and net operating profit as dependent variable. We have found a significant negative relationship between net operating profitability and the average collection period, inventory turnover in days, average payment period and cash conversion cycle for a sample of Pakistani firms listed on Karachi stock exchange. Previous theoretical research predicts negative relationship between cash conversion cycle and corporate profitability. The results of regression indicate that the coefficient of account receivable is negative; that is, the increase or decrease in average collection period wills significantly affect the profitability of the firm. According to inter-item correlation matrix the relationship of account receivables, account payables and inventory with profit shows positive relationship but cash conversion cycle, financial debt and financial assets shows negative relationship with profitability. Inventory shows the positive relationship with dependent variable which proves that working capital management has a positive effect on firm's probability.
\end{abstract}

Keywords: Gross operating profit; Working capital management; Probability of firms; Manufacturing Industry of Pakistan; Efficient working capital management

\section{INTRODUCTION}

Working capital management is very important element of any corporate finance because it directly influences the liquidity and profitability of the company. It deals with Current assets and current liabilities. Working capital management is important due to many causes. For one thing, the current assets of a distinctive manufacturing firm accounts for over half of its total assets. For a distribution company, their financial account for even more. Too many levels of current assets can easily result in a firm's realizing an inferior return on investment. However firms with too few current assets may incur shortages and difficulties in maintaining smooth operations (Horne and Wachowicz, 2000). Efficient working capital management involves planning and controlling current assets and current liabilities in a manner that eliminates the risk of inability to meet due short term obligations on the one hand and avoid excessive investment in these assets on the other hand (Eljelly, 2004). Liquidity for 
the ongoing firm is not reliant on the liquidation value of its assets, but rather on the operating cash flows generated by those assets (Soenen, 1993).

Taken collectively, result on the level of different working capital components become regular, boring, and time consuming. Working Capital Management is a very sensitive area in the field of financial management (Joshi, 1994). It engages the decision of the amount and work of current assets and the investment of these assets. Current assets comprise all those assets that in the normal way of business return to the form of cash within a short period of time, normally within a year and such temporary investment as may be eagerly converted into cash upon need. The Working Capital Management of a firm in part influences its profitability. The definitive purpose of any firm is to maximize the profit. But, protecting liquidity of the firm is an important objective too.

The problem is that increasing profits at the cost of liquidity can bring serious problems to the firm. Therefore, there must be a tradeoff between these two objectives of the firms. One objective should not be at cost of the other because both have their importance. If we do not think about profit, we cannot survive for a longer period. On the other hand, if we do not think about liquidity, we may face the problem of insolvency or bankruptcy. For these reasons working capital management should be given proper consideration and will eventually affect the profitability of the firm. Firms may have an most advantageous level of working capital that take advantage of their value. Large inventory and a generous trade credit policy may show the way to high sales. Larger inventory decrease the risk of a stockout. Trade credit may stimulate sales because it allows customers to assess product quality before paying (Long, Maltiz and Ravid, 1993, and Deloof and Jegers, 1996).

Another component of working capital is accounts payable. Delaying payments to suppliers allows a firm to appraise the quality of bought products, and can be a low-priced and flexible source of financing for the firm. On the other hand, late payment of invoices can be very costly if the firm is offered a discount for early payment. A popular measure of Working Capital Management (WCM) is the cash conversion cycle, i.e. the time lag between the expenditure for the purchases of raw materials and the collection of sales of finished goods.

The longer this time lag, the larger the investment in working capital (Deloof, 2003). A longer cash conversion cycle might increase profitability because it leads to higher sales. However, corporate profitability might also decrease with the cash conversion cycle, if the costs of higher investment in working capital rise faster than the benefits of holding more inventories and/or granting more trade credit to customers. It requires constant supervising to maintain proper intensity in various components of working capital i.e. cash receivables, inventory and payables etc.

The purpose of this study is to explore the important aspect of financial management Known as working capital management. It is almost untouched in Pakistan or very little research has been done in this area so This research is focusing on working capital management and its effects on profitability for a sample of Pakistani firms and analyzing and establish a relationship between Working Capital Management and Profitability and effects of different components of working management on probability in manufacturing sector of Pakistan (Nadeem Iqbal, et.al., 2014).

\section{1. Literature Review}

Many researchers have studied working capital from different views and in different environments. The following ones were very interesting and useful for our research: (Eljelly, 
2004) elucidated that efficient liquidity management involves planning and controlling current assets and current liabilities in such a manner that eliminates the risk of inability to meet due short-term obligations and avoids excessive investment in these assets. The relation between profitability and liquidity was examined, as measured by current ratio and cash gap (cash conversion cycle) on a sample of joint stock companies in Saudi Arabia using correlation and regression analysis. The study found that the cash conversion cycle was of more importance as a measure of liquidity than the current ratio that affects profitability. The size variable was found to have significant effect on profitability at the industry level. (Deloof, 2003) discussed that most firms had a large amount of cash invested in working capital. It can therefore be expected that the way in which working capital is managed will have a significant impact on profitability of those firms. Using correlation and regression tests he found a significant negative relationship between gross operating income and the number of days accounts receivable, inventories and accounts payable of Belgian firms. On basis of these results he suggested that managers could create value for their shareholders by reducing the number of days' accounts receivable and inventories to a reasonable minimum. The negative relationship between accounts payable and profitability is consistent with the view that less profitable firms wait longer to pay their bills.

(Ghosh and Maji, 2003) in this paper made an attempt to examine the efficiency of working capital management of the Indian cement companies during 1992 - 1993 to 2001 2002. For measuring the efficiency of working capital management, performance ,utilization, and overall efficiency indices were calculated instead of using some common working capital management ratios. Findings of the study indicated that the Indian Cement Industry as a whole did not perform remarkably well during this period. (Shin and Soenen, 1998) highlighted that efficient Working Capital Management (WCM) was very important for creating value for the shareholders. The way working capital was managed had a significant impact on both profitability and liquidity. (Smith and Begemann, 1997) emphasized that those who promoted working capital theory shared that profitability and liquidity comprised the salient goals of working capital management. The problem arose because the maximization of the firm's returns could seriously threatens its liquidity, and the pursuit of liquidity had a tendency to dilutee turns.

This article evaluated the association between traditional and alternative working capital measures and return on investment (ROI). The problem under investigation was to establish whether the more recently developed alternative working capital concepts showed improved association with return on investment to that of traditional working capital ratios or not. Results indicated that there were no significant differences amongst the years with respect to the independent variables. The results of their step wise regression corroborated that total current liabilities divided by funds flow accounted for most of the variability in Return on Investment (ROI). The statistical test results showed that a traditional working capital leverage ratio, current liabilities divided by funds flow, displayed the greatest associations with return on investment. Well known liquidity concepts such as the current and quick ratios registered insignificant associations whilst only one of the newer working capital concepts, the comprehensive liquidity index, indicated significant associations with return on investment. Mathuva [11, p. 1] examined the influence of working capital management components on corporate profitability by using a sample of 30 firms listed on the Nairobi Stock Exchange (NSE) for the periods 1993 to 2008. He used Pearson and Spearman's correlations, the pooled ordinary least square (OLS), and the fixed effects regression models to conduct data analysis. The key findings of his study were that: i) there exists a highly significant negative relationship between the time it takes for firms to collect cash from their 
customers (accounts collection period) and profitability, ii) there exists a highly significant positive relationship between the period taken to convert inventories into sales (the inventory conversion period) and profitability, and iii) there exists a highly significant positive relationship between the time it takes the firm to pay its creditors (average payment period) and profitability.

All the above studies provide us a solid base and give us idea regarding working capital management and its components. Table 1 below summarizes the definitions and theoretical predicted signs. Note that previous studies provide no clear-cut direction of the relationship between any of the variables and firm's profitability.

This discussion of the importance of working capital management, its different components and its effects on profitability leads us to the problem statement which we will be analyzing. Manufacturing is the second largest sector of the economy of Pakistan after agriculture sector and it accounts for $19.1 \%$ of GDP. It grew by 8.4 percent during 2007 as against 10 percent last year. In the manufacturing sector, large scale manufacturing plays a vital role and accounts for approximately 70 percent of overall manufacturing (Government of Pakistan, 2006-07). As an important sector in the overall economic growth, manufacturing sector requires in depth analysis at industry as well as firm level. The sector is dominated by textile, oil and gas, cement and automobile sectors in terms of assets size and credit allocation. Working capital management efficiency is vital especially for manufacturing firms, where a major part of assets is composed of current assets (Horne and Wachowitz, 2000). It directly affects the profitability and liquidity of firms (Raheman and Nasr, 2007). An optimal level of working capital would be the one in which a balance achieved between risk and efficiency.

Table 1. Proxy variables definition and predicted relationship.

Proxy Variables Definitions

Predicted sign

AR Accounts receivables divided by sales and multiplied by 365 days $+/$ -

AP Accounts payables divided by cost of goods sold and multiplied by 365 days +/-

INV Inventory divided by cost of goods sold and multiplied by 365 days +/-

CCC No. of days A/R plus No. of days inventory minus No. of days A/P +/-

FD Short-term loans plus long-term loans divided by the total assets $+/-$

FFA Fixed financial assets divided by the total assets $+/-$

\section{METHODOLOGY}

A database was built from a selection of approximately 50 financial-reports that were made public by publicly traded companies of Pakistan between January 1, 2009 and December 31, 2009. The selection is drawn from a random sample of manufacturing companies. Out of approximately 50 financial-reports announced by public companies between January 1, 2009 and December 31, 2009, only 10 financial reports were useable and selected for our research and data analyzed. In this research study these variables are used for empirical result. To remain consistent with previous studies, measures pertaining to working capital management and profitability were taken from Lazaridis and Tryfonidis's [1, p. 28] study. They used cross sectional yearly data and measured the variables as follows: 
No. of Days $A / R=($ Accounts Receivables/Sales $) \times 365$

No. of Days $A / P=($ Accounts Payables/Cost of Goods Sold $) \times 365$

No. of Days Inventory $=($ Inventory/Cost of Goods Sold $) \times 365$

Cash Conversion Cycle $=($ No. of Days A/R + No. of Days Inventory $)-$ No. of Days A/P

Financial Debt Ratio $=$ Short term loans + long term loans/total assets

Fixed Financial Asset Ratio $=$ Fixed Financial Assets/Total assets

Profit $=($ Sales - Cost of Goods Sold $) /($ Total Assets - Financial Assets $)$

We used all the above variables. Fixed financial asset ratio used as a control variable. In order to obtain dependent variable (gross operating profit), we subtract cost of goods sold from total sales and divide the results with total assets minus financial assets. The reason for using this variable instead of earnings before interest tax depreciation amortization (EBITDA) or profit before or after tax is that we want to associate operating "success" or "failure" with an operating ratio and relate this variable with other operating variables (e.g., cash conversion cycle). Furthermore, we want to exclude the participation of any financial activity from operating activity that might affect overall profitability. Therefore, we subtracted financial assets from total assets.

\section{Variables}
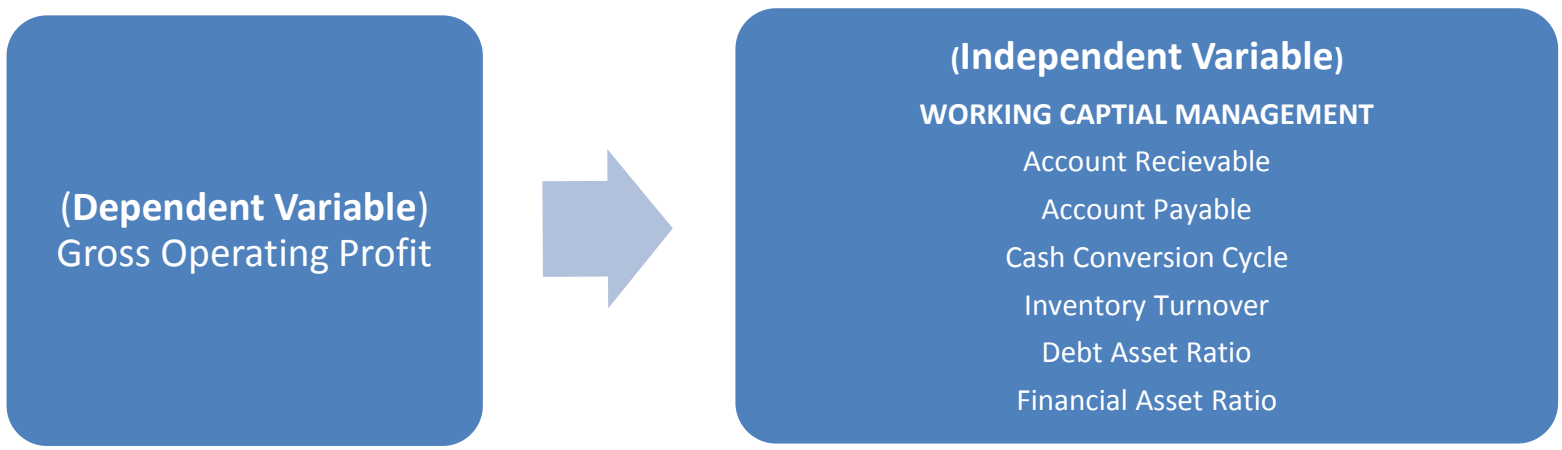

\section{Data Collection}

A database was built from a selection of approximately 50 financial-reports that were made public by publicly traded companies between January 1, 2009 and December 31, 2009. The selection is drawn from a random sample of manufacturing companies. Out of approximately 50 financial-reports announced by public companies between January 1, 2009 and December 31, 2009, only 10 financial reports were useable. We used cross sectional yearly data in this study. Thus, 10 financial reports resulted to 10 total observations. Since random sampling method was used to select companies, we consider the sample as a representative sample. For the purpose of this research, certain industries were omitted due to the type of activity. For example, we omitted all the companies from the service industry. In addition, some of the firms were not included in the data due to lack of information for the certain time. All the certain companies listed and registered from KSE, Pakistan. 


\section{RESULTS AND DISCUSSION}

Results from data is presented in descriptive statistics and regression analysis as under.

\section{1. Descriptive Statistics}

Table 2 provides descriptive statistics of the collected variables. All variables were calculated using balance sheet (book) values. The book value was used because the companies did not provide any market value related to the variables that we used in this study. In addition, the measurement of profitability could only be based on income statement values, not on so-called market values. The explanatory variables are all firm specific quantities and there is no way to measure these variables in terms of their 'market value.' Furthermore, when market values are considered in such studies, there is always a rather legitimate question of the date for which the 'market values' refer. This is rather arbitrary. Hence, we relied on 'book values' as of the date of the financial reports.

Total observations come to $10 \times 1=10$. The credit period granted by companies to their clients ranged at 35.3 days while they paid their creditors in 90.5 days on average. Inventory took on an average 77.50 days to be sold. Overall, the average cash conversion cycle ranged at 22.29 days.

Table 2. Descriptive Statistics of Independent, Dependent, and Control Variables.

Descriptive Statistics

\begin{tabular}{lccccc}
\hline \hline & $\mathrm{N}$ & Minimum & Maximum & Mean & Std. Deviation \\
& & & & & \\
\hline AR & 10 & .47 & 84.33 & 35.3000 & 25.97437 \\
AP & 10 & 24.49 & 311.94 & 90.5080 & 93.15025 \\
INV & 10 & 6.64 & 145.95 & 77.5050 & 48.15821 \\
CCC & 10 & -81.66 & 134.43 & 22.2980 & 68.58280 \\
FD & 10 & .00 & 11.67 & 1.4310 & 3.60543 \\
FA & 10 & .00 & 1.44 & .1833 & .44420 \\
PROFIT & 10 & -1.18 & .59 & .1125 & .48894 \\
Valid N (list wise) & 10 & & & & \\
\hline \hline
\end{tabular}




\section{2. Regression}

\section{Model Summary}

\begin{tabular}{cccccccccc}
\hline \hline Model & $\mathrm{R}$ & $\mathrm{R}$ & Adjusted R \\
& Square & Square & Std. Error of \\
the Estimate & R Square & Change Statistics \\
Change & Change & df1 & df2 & $\begin{array}{c}\text { Sig. F } \\
\text { Change }\end{array}$ \\
\hline 1 & $.198^{\mathrm{a}}$ & .039 & -.441 & .58702 & .039 & .081 & 3 & 6 & .968 \\
\hline \hline
\end{tabular}

a. Predictors: (Constant), CCC, AR, INV

In model summary we calculate " $\mathrm{R}$ " and $\mathrm{R}$ square in order to check out the relationship among CCC, AR and INV variables.

\begin{tabular}{ccccccc}
\hline \multicolumn{10}{c}{ ANOVA $^{\mathbf{a}}$} & & & \\
\hline \hline & Model & $\begin{array}{c}\text { Sum of } \\
\text { Squares }\end{array}$ & df & $\begin{array}{c}\text { Mean } \\
\text { Square }\end{array}$ & F & Sig. \\
\hline \multirow{2}{*}{1} & Regression & .084 & 3 & .028 & .081 & $.968^{\mathrm{b}}$ \\
& Residual & 2.068 & 6 & .345 & & \\
\hline \hline
\end{tabular}

a. Dependent Variable: PROFIT

b. Predictors: (Constant), CCC, AR, INV

Here ANOVA shows the relationship among dependent and independent variables.

\section{Coefficients*}

\begin{tabular}{|c|c|c|c|c|c|c|c|c|}
\hline & \multirow[t]{3}{*}{ Model } & \multicolumn{2}{|c|}{$\begin{array}{l}\text { Unstandardized } \\
\text { Coefficients }\end{array}$} & \multirow{3}{*}{$\begin{array}{c}\text { Standardized } \\
\text { Coefficients } \\
\text { Beta }\end{array}$} & \multirow[t]{3}{*}{$\mathrm{t}$} & \multirow[t]{3}{*}{ Sig. } & \multicolumn{2}{|c|}{$\begin{array}{c}95.0 \% \text { Confidence Interval } \\
\text { for B }\end{array}$} \\
\hline & & B & Std. Error & & & & Lower & Upper \\
\hline & & & & & & & Bound & Bound \\
\hline \multirow{4}{*}{1} & (Constant) & .094 & .368 & & .255 & .807 & -.806 & .993 \\
\hline & $\mathrm{AR}$ & -.001 & .012 & -.069 & -.103 & .921 & -.032 & .029 \\
\hline & INV & .001 & .007 & .123 & .183 & .861 & -.015 & .018 \\
\hline & $\mathrm{CCC}$ & -.001 & .003 & -.204 & -.485 & .645 & -.009 & .006 \\
\hline
\end{tabular}

*Dependent Variable: PROFIT

In this table "B" (beta) and confidence interval shows the level of significance. 


\section{3. Reliability Reliability}

\begin{tabular}{ccc} 
& Statistics \\
\hline \hline Cronbach's Alpha & $\begin{array}{c}\text { Cronbach's Alpha } \\
\text { Based on } \\
\\
\end{array}$ & N of Items \\
& & \\
\hline .197 & .088 & 7 \\
\hline \hline
\end{tabular}

Reliability shows the data consistency. Cronbach's Alpha shows .197 it shows that cronbach's alpha is more reliable.

Inter-Item Correlation Matrix

\begin{tabular}{lrrrrrrr}
\hline \hline & \multicolumn{1}{c}{ AR } & \multicolumn{1}{c}{ AP } & \multicolumn{1}{c}{ INV } & \multicolumn{1}{c}{ CCC } & \multicolumn{1}{l}{ FD } & \multicolumn{1}{l}{ FA } & PROFIT \\
\hline AR & 1.000 & .707 & .780 & -.034 & -.191 & -.193 & .034 \\
AP & .707 & 1.000 & .613 & -.660 & -.273 & -.242 & .162 \\
INV & .780 & .613 & 1.000 & .166 & -.010 & -.046 & .036 \\
CCC & -.034 & -.660 & .166 & 1.000 & .291 & .224 & -.181 \\
FD & -.191 & -.273 & -.010 & .291 & 1.000 & .996 & -.940 \\
FA & -.193 & -.242 & -.046 & .224 & .996 & 1.000 & -.954 \\
PROFIT & .034 & .162 & .036 & -.181 & -.940 & -.954 & 1.000 \\
\hline \hline
\end{tabular}

We calculate inter-item Correlation Matrix in order to check the combine effect of independent and control variables on the dependent variable (profit).

\section{Summary Item Statistics}

\begin{tabular}{ccccccccc}
\hline \hline & Mean & $\begin{array}{c}\text { Minim } \\
\text { um }\end{array}$ & $\begin{array}{c}\text { Maxim } \\
\text { um }\end{array}$ & Range & $\begin{array}{c}\text { Maximum / } \\
\text { Minimum }\end{array}$ & Variance & $\begin{array}{c}\text { N of } \\
\text { Items }\end{array}$ \\
\hline Item Means & 32.477 & .113 & 90.508 & 90.395 & 804.444 & 1426.816 & 7 \\
& 2341.1 & .197 & 8676.9 & 8676.7 & & 43976.118 & $\begin{array}{c}10813602 . \\
916\end{array}$ & 7 \\
Item Variances & 26 & 68 & 71 & & & \\
Inter-Item & & & & & & & & \\
Correlations & .014 & -.954 & .996 & 1.951 & -1.044 & .251 & 7 \\
\hline \hline
\end{tabular}

Summary item statistics is calculated to sum up all the findings of item Means, Variance and Inter-item Correlations to check out the relationships among them. 


\section{Scale Statistics}

\begin{tabular}{cccc}
\hline \hline Mean & Variance & Std. Deviation & N of Items \\
\hline \multirow{2}{*}{227.3378} & 19710.645 & 140.39460 & 7 \\
\hline \hline
\end{tabular}

This table shows the Mean, Variance and standard deviation of all the Dependent, Independent and control variables.

\section{DISCUSSION}

In this research paper we take working capital as independent variable and net operating profit as dependent variable. We have found a significant negative relationship between net operating profitability and the average collection period, inventory turnover in days, average payment period and cash conversion cycle for a sample of Pakistani firms listed on Karachi stock exchange. Previous theoretical research predicts negative relationship between cash conversion cycle and corporate profitability. The results of regression indicate that the coefficient of account receivable is negative; that is, the increase or decrease in average collection period wills significantly affect the profitability of the firm. According to reliability statistics cronbatch's alpha shows .197 but standardized items shows .088 and number of item are 7. According to inter-item correlation matrix the relationship of account receivables, account payables and inventory with profit shows positive relationship but cash conversion cycle, financial debt and financial assets shows negative relationship with profitability. In addition negative relationship between account receivables and the firm's profitability suggest that less profitable firms will pursue a decrease of their account receivables in an attempt to reduce their cash gap in the cash conversion cycle. Inventory shows the positive relationship with dependent variable. That proves that working capital management has a positive effect on firm's probability.

\section{CONCLUSION}

The contribution of manufacturing sector, the second largest sector of economy, plays a significant role in the economic growth of Pakistan. Most of Pakistani firms have large amounts of cash invested in working capital. It can therefore be expected that the way in which working capital is managed will have a significant impact on profitability of those firms. The results shows that for overall manufacturing sector, working capital has significant impact on profitability of the firms and plays a key role in value creation for shareholders as longer cash conversion cycle have negative impact on net operating profitability of a firm. On basis of the above analysis we may further conclude that these results can be further strengthened if the firms manage their working capital in more efficient ways. Management of working capital means "management of current assets and current liabilities, and financing these current assets". If these firms properly manage their cash, accounts receivables and inventories in a proper way, this will ultimately increase profitability of these companies. 
There is much to be done about working capital in Pakistan in future. We suggest that further research be conducted on the same topic with different companies and extending the years of the sample. The scope of the working capital components management including cash, marketable securities, receivables and inventory management. Furthermore, efficient Management and financing of working capital (current assets and current liabilities) can increase the operating profitability of manufacturing firms. For efficient working capital management, specialized persons in the fields of finance should be hired by the firms for expert advice in the manufacturing sector because there are number of firms where there is only one department and one person who is looking after all financial activities of firms including handling of accounts etc.

\section{References}

[1] A, E. (2004). Liquidity-profitability tradeoff: an empirical investigation in an emerging market. International Journal of Commerce and Management, , 14, 48-61.

[2] Afza, T. a. (2008). Working Capital Approaches and Firm's Returns. Pakistan Journal of Commerce and Social Sciences 1(1), 25-36.

[3] Baltagi, B. H. (2001). Econometric Analysis of Panel Data. (2, Ed.) John Wiley \& Sons. Chichester.

[4] Besley S, M. R. (1987). An empirical investigation of factors affecting the cash conversion cycle. Paper Presented at the Annual Meeting of the Financial Management Association. Las Vegas, Nevada.

[5] Blinder, A. S. (1991). Taking Stock: A critical Assessment of Recent Research on Inventories. Journal of Economic Perspectives 5(1), 73-96.

[6] Czyzewski, A. a. (1992). Hold Onto Your Cash. Management Accounting.

[7] D, M. (2009). The influence of working capital management components on corporate profitability: a survey on Kenyan listed firm. Research Journal of Business Management 3.

[8] Deloof, M. a. (1996). Trade credit, product Quality, and Intra Group Trade: Some European Evidence. Financial Management 25(3), 33-43.

[9] Deloof, M. (2003). Does Working Capital Management Affects profitability of Belgian Firms. 30(3\&4), Journal of Business Finance \& Accounting 30(3\&4), 0306-686X.

[10] Deloof, M. (2003). Does Working Capital Management Affects Profitability of Belgian Firms? Journal of Business Finance \& Accounting 30(3\&4), 573-587.

[11] Economic Survey of Pakistan. (2006-07). Finance Division . Government of Pakistan.

[12] Eljelly, A. (2004). Liquidity-Profitability Tradeoff: An empirical Investigation in an Emerging Market. International Journal of Commerce \& Management 14(2), 48-61.

[13] Eljelly, M. (2004). Liquidity - Profitability Tradeoff: An empirical investigation in an emerging market. International Journal of Commerce \& Management 14(2).

[14] Falope OI, A. O. (2009). Working capital management and corporate profitability: evidence from panel data analysis of selected quoted companies in Nigeria. Research Journal of Business Management 3, 73-84.

[15] Filbeck, G. a. (2005). An Analysis of Working Capital Management results across Industries. American Journal of Business 20(2), 11-18.

[16] Garcia-Teruel PJ, M.-S. P. (2007). Effects of working capital management on SME profitability. International Journal of Managerial Finance, 164-177. 
[17] Garcia-Teruel, P. a.-S. (2007). Effects of Working Capital Management on SME Profitability. International Journal of Managerial Finance, 3(2), 164-177.

[18] Ghosh S. K, M. S. (2003). Working capital management efficiency: a study on the Indian cement industry. Retrieved from The Institute of Cost and Works Accountants of India: http://www.icwai.org/icwai/knowledgebank/fm47.pdf]

[19] Ghosh SK, M. S. (n.d.). Working capital management efficiency: a study on the Indian cement industry. Retrieved from http://www.icwai.org/icwai/knowledgebank/fm47.pdf

[20] Ghosh, S. K. (2003). Working Capital Management Efficiency: A study on the Indian Cement Industry. The Institute of Cost and Works Accountants of India.

[21] Gitman, L. (1991). Principles of Managerial Finance.Collins Publishers Inc. Harper, New York.

[22] Hausman, J. (1978). Specification Tests in Econometrics. Econometrica, 46, 1251-71.

[23] Jose, M. L. (1996). Corporate Returns and Cash Conversion Cycles. Journal of Economics and Finance, 20(1), 33-46.

[24] Joshi, P. V. (1995). Working Capital Management under Inflation. (1, Ed.) Anmol Publishers, 20-93.

[25] Kargar, J. a. (1994). Leverage Impact of Working Capital in Small Businesses. TMA Journal, 14(6), 46-53.

[26] Lazaridis I, T. D. (2006). Relationship between working capital management and profitability of listed companies in the Athens stock exchange. Journal of Financial Management and Analysis, 26-25.

[27] Lazaridis, I. a. (2006). Tryfonidis Relationship between Working Capital Management and Profitability of Listed Companies in the Athens Stock Exchange. Journal of Financial Management and Analysis, 19(1), 26-35.

[28] Long MS, M. I. (1993). Trade credit, quality guarantees, and product marketability. Financial Managemen, 117-124.

[29] Long, M. S. (1993). Trade Credit, Quality Guarantees, and Product Marketability. Financial Management, 117-127.

[30] M, D. (2003). Does working capital management affect profitability of Belgian firms. Journal of Business Finance and Accounting, 30, 573-588.

[31] Mukhopadhyay, D. (2004). Working Capital Management in Heavy Engineering Firms. Retrieved from myicwai.com/knowledgebank/fm48.

[32] Raheman A, N. M. (2007). Working capital management and profitability - case of Pakistani firms. Research Paper.

[33] Rao, R. K. (1989). Fundamentals of Financial Management. (3, Ed.)

[34] Ricci, C. a. (2000). International Working Capital Practices in the UK. European Financial Management, 6(1), 69-84.

[35] Richard, V. D. (1980). A Cash Conversion Cycle Approach to Liquidity Analysis. Financial Management, 9(1), 32-38.

[36] Shin HH, S. L. (1998). Efficiency of working capital management and corporate profitability. Financial Practice and Education, 37-45.

[37] Shin, H. a. (1998). Efficiency of Working Capital Management and Corporate Profitability. Financial Practice and Education, 8(2), 37-45.

[38] Smith, M. B. (1997). Measuring Association between Working Capital and Return on Investment. South African Journal of Business Management, 28(1).

[39] Soenen, L. A. (1993). Cash conversion cycle and corporate profitability. Journal of Cash Management, 13(4), 53-58. 
[40] Van Horne, J. C. (2000). Fundamentals of Financial Management (11 ed.). Prentice Hall Inc.

[41] Nadeem Iqbal, Naveed Ahmad, Zeeshan Haider, Sonia Anwar, International Letters of Social and Humanistic Sciences 5 (2014) 73-80.

[42] Nadeem Iqbal, Naveed Ahmad, Komal Javaid, International Letters of Social and Humanistic Sciences 6 (2014) 60-73.

[43] Nadeem Iqbal, Naveed Ahmad, Maira Abrar, Aisha Hassan, International Letters of Social and Humanistic Sciences 7 (2014) 31-43. 